\title{
A SUMMARY OF THE PHASE II - TITLE I ENGINEERING ASSESSMENT OF INACTIVE URANIUM MILL TAILINGS LOWMAN SITE, LOWMAN, IDAHO
}

DECEMBER 1977

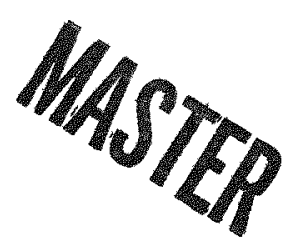

PREPARED FOR

UNITED STATES DEPARTMENT OF ENERGY

GRAND JUNCTION, COLORADO, CONTRACT NO. E(05-1)-1658

BY

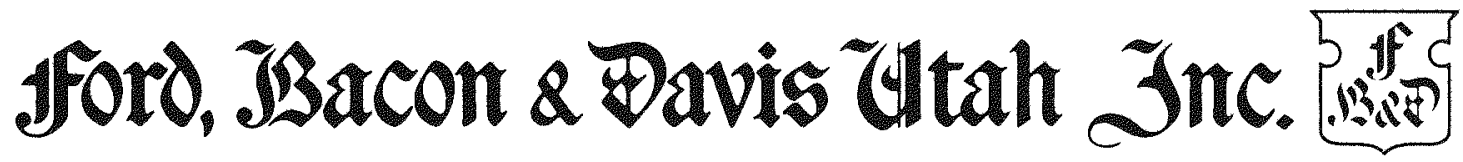




\section{DISCLAIMER}

This report was prepared as an account of work sponsored by an agency of the United States Government. Neither the United States Government nor any agency Thereof, nor any of their employees, makes any warranty, express or implied, or assumes any legal liability or responsibility for the accuracy, completeness, or usefulness of any information, apparatus, product, or process disclosed, or represents that its use would not infringe privately owned rights. Reference herein to any specific commercial product, process, or service by trade name, trademark, manufacturer, or otherwise does not necessarily constitute or imply its endorsement, recommendation, or favoring by the United States Government or any agency thereof. The views and opinions of authors expressed herein do not necessarily state or reflect those of the United States Government or any agency thereof. 


\section{DISCLAIMER}

Portions of this document may be illegible in electronic image products. Images are produced from the best available original document. 
A SUMMARY OF THE PHASE II - TITLE I

ENGINEERING ASSESSMENT OF

RADIOACTIVE SANDS AND RESIDUES

LOWMAN SITE

LOWMAN, IDAHO

DECEMBER 1977

Prepared For

U.S. DEPARTMENT OF ENERGY

GRAND JUNCTION, COLORADO

Contract No. $E(05-1)-1658$

BYy

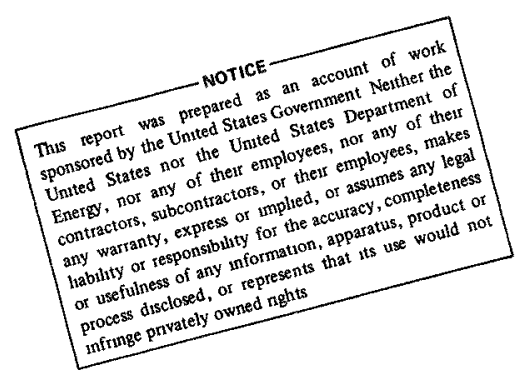

FORD, BACON \& DAVIS UTAH INC.

375 Chipeta way

Salt Lake City, Utah 84108

FB\&DU $130-17$ 


\section{NOTICE}

This Phase II - Title I Engineering Assessment has been performed under ERDA Contract No. E(05-I)-1658 executed on June 23, 1975 between the U.S. Energy Research and Development Administration and Ford, Bacon \& Davis Utah Inc. On October I, 1977. ERDA was incorporated into the U.S. Department of Energy: hence, this engineering assessment is issued for the DOE, the present responsible agency. 
FOREWORD

This report is a summary of a parent report entitled, "Phase II - Title I Engineering Assessment of Radioactive Sands and Residues, Lowman Site, Lowman, "Idaho". Both reports are authorized under the U.S. Energy Research and Development Administration (ERDA) Contract No. E(05-1)-1658. The reports are part of a series of reports on inactive uranium millsites, and address the radiological problems and estimated costs of remedial measures that would reduce exposure of the general public. Title I is not a scientific study but an engineering assessment to determine the relative magnitude of the hazards associated with each site, and to estimate the remedial action costs. If additional information that may alter or have an impact on a final remedial action decision for any site is required, it can be obtained during the Title II Engineering Effort.

Ford, Bacon \& Davis Utah Inc. (FB\&DU) under supplemental authorization currently is investigating uranium mill tailings stabilization techniques. This research could modify some of the estimated costs in this report.

Also, FB\&DU acknowledges the excellent cooperation and assistance given in this engineering assessment. Particular recognition is due the ERDA personnel of both the Germantown, MD and Grand Junction, Co offices and also the Union Carbide Corporation personnel of the Health Physics Division, Oak Ridge National Laboratory, who provided field radiological measurements and radiometric analyses of samples. The preparation of this report could not have been accomplished without the cooperation and assistance of the following:

(1) The Environmental Protection Agency; for consultation, data, and information from prior studies with notable assistance from the Office of Radiation Programs, Las Vegas, Nevada

(2) Michigan Chemical Corporation

(3) EG\&G; Las Vegas, Nevada; Mr. Jack Doyle; for aerial photography

(4) Center for Health and Environmental Studies, Brigham Young University, Provo, Utah; for socioeconomic studies

(5) Mr. Gary Boothe, formerly with Idaho Department of Health and Welfare 
Ford, Bacon \& Davis Utah Inc. has performed an engineering assessment of the problems resulting from the existence of radioactive uranium sand residues at the Lowman, Idaho site. The Phase II - Title I services normally include the preparation of topographic maps, the performance of core drillings and radiometric measurements sufficient to determine areas and volumes of tailings and other radium-contaminated materials, the evaluation of resulting investigation of site hydrology and meteorology, and the evaluation and costing of alternative corrective actions.

Radon gas release from the 90,000 tons of sand residues at the Lowman site constitutes the most significant environmental impact, although external gamma radiation is also a factor. The two alternative actions presented are dike construction, fencing, and maintenance (Option I); and consolidation of the piles, addition of a 2-ft-thick stabilization cover, and on-site cleanup (Option II). Both options include remedial action at off-site structures. Cost estimates for the two options are $\$ 393,000$ and $\$ 590,000$.

Reprocessing the sand residues for uranium recovery is not economically attractive at present. 
CONTENTS

Chapter

Title

Page

Foreword

Abstract

ii

Glossary

iii

$\mathrm{x}$

A SUMMARY OF THE PHASE II - TITLE I ENGINEERING ASSESSMENT OF RADIOACTIVE SANDS AND RESIDUES

1.I Introduction. ............ . 1-1

1.1.1 Background ......... 1-2

1.1.2 Scope of Phase II

Engineering Assessment . . . 1-3

1.2 Site Description. . . . . . . . 1-5

1.2.1 Location and Topography. . . 1-5

1.2.2 Ownership and History of

Milling Operations and

Processing........ . $1-5$

1.2.3 Present Condition of the

$1-5$

1.2 .4 Residues and Soil ${ }^{\circ} \cdot *^{*} \quad 1-6$

Residues and Soil
Characteristics. . . . . . $1-6$

1.2.5 Geology, Hydrology, and
Meteorology. . . . . . $1-6$

1.3 Radioactivity and Pollutant

Impacts on the Environment. . . . . 1-7

1.3.1 Radiation Exposure Pathways,

Contamination Mechanisms,

and Background Levels. . . . 1-8

1.3.1.1 Radon Gas Diffusion

and Transport. . . 1-8

1.3.1.2 Direct Gamma

1.3.1.3 Windblown

$1-8$

Contaminants. . . . 1-9

1.3.1.4 Ground and Surface
Water Contamination. I-9

1.3.1.5 Soil Contamination. . 1-9

1.3.2 Remedial Action Criteria . . 1-9

1.3.3 Potential Health Impact. . . 1-11

1.3.4 Nonradioactive Pollutants. . . 1-12 
CONTENTS (Cont)

Chapter

Title

$\underline{\text { Page }}$

1.4 Socioeconomic and Land Use

Impacts . . . . . . . . . . . $1-12$

1.5 Recovery of Residual Values..... . 1-13

1.6 Mill Tailings Stabilization ..... . 1-13

1.7 Off-Site Remedial Actions...... 1-13

1.8 Long-Term Storage Site Selection. . 1-14

1.9 Remedial Actions and Cost Benefit

Analyses. . . . . . . . . . . 1-14

1.9.1 Remedial Action Options. . . 1-14

1.9.2 Cost Benefit Analyses. . . . 1-14

Chapter 1 References . . . . . . . . 1-18

ADDENDUM - FIGURES AND TABLES . . . . . 1-20 
Abbreviations/Terms

absorbed dose

$A-E$

AEC

alpha particle $(\alpha)$

amenability

anomaly (mobile gamma survey)

aquifer

atmospheric pressure

background radiation

beta particle ( $\beta$ )

\section{Definitions}

Radiation energy absorbed per unit mass.

Architect-Engineer.

Atomic Energy Commission.

A positively charged particle emitted from certain radioactive material. It consists of two protons and two neutrons, hence is identical with the nucleus of the helium atom. It is the least penetrating of the common radiation $(\alpha, \beta, \gamma)$, hence is not dangerous unless alpha-emitting substances have entered the body.

The relative ease with which a mineral(s) can be removed from an ore by a particular process.

Any location detected by the mobile gamma survey where the recorded counts per second (c/s) from a large gammaray detector exceed the determined background for that area by 50 or more $\mathrm{c} / \mathrm{s}$.

A water-bearing formation below the surface of the earth; the source of wells. A confined aquifer is overlain by relatively impermeable rock. An unconfined aquifer is one associated with the water table.

Pressure exerted on the earth by the mass of the atmosphere surrounding the earth; expressed in inches of mercury (at sea level and $0^{\circ} \mathrm{C}$, standard pressure is 29.921 in. $\mathrm{Hg}$ ).

Naturally occurring low-level radiation to which all life is exposed. Background radiation levels vary from place to place on the earth.

A particle emitted from some atoms undergoing radioactive decay. A negatively charged beta particle 
BEIR

BOM (USBOM)

CHES

$\mathrm{Ci}$

daughter product

diurnal

dose equivalent

EGR

EPA (USEPA)

ERDA (USERDA)

ERDA-GJO

erg is identical to an electron. A positively charged beta particle is called a positron. Beta radiation can cause skin burns and betaemitters are harmful if they enter the body.

Biological Effects of Ionizing Radiation.

Bureau of Mines.

Center for Health and Environmental Studies, Brigham Young University, Provo, Utah.

Curie (the unit of radioactivity of any nuclide, defined as precisely equal to $3.7 \times 1010$ disintegrations/second).

The nuclide remaining after a radioactive decay. A daughter atom may itself be radioactive. producing further daughter products.

Daily, cyclic (happening each day or during the day).

A term used to express the amount of effective radiation when modifying factors have been considered (the numerical product of absorbed dose and quality factor).

External gamma radiation (gamma radiation emitted from a source(s) external to the body, as opposed to internal gamma radiation emitted from ingested or inhaled sources).

Environmental Protection Agency.

Energy Research and Development Administration.

Energy Research and Development Administration-Grand Junction office.

The basic unit of work or energy in the centimeter-gram-second. 
exposure

exhalation

FB\&DU

gamma background

gamma ray

GJO

ground water

health effect

heap leaching

HEW (USHEW) system ( 1 erg is equal to $7.4 \mathrm{x}$ $\left.10^{8} \mathrm{ft}-1 \mathrm{~b}\right)$.

Related to electrical charge produced in air by ionizing radiation per unit mass of air.

Emission of radon from earth (usually thought of as coming from a uranium tailings pile, but actually from any location).

Ford, Bacon \& Davis Utah Inc.

Natural gamma ray activity everywhere present, originating from two sources: (1) cosmic radiation, bombarding the earth's atmosphere continually, and (2) terrestrial radiation. Whole body absorbed dose equivalent in the U.S. due to natural gamma background ranges from about 60 to about $125 \mathrm{mrem} / \mathrm{yr}$.

High energy electromagnetic radiation emitted from the nucleus of a radioactive atom, with specific energies for the atoms of different elements and having high penetrating power.

Grand Junction Office.

Subsurface water in the zone of full saturation which supplies wells and springs.

Adverse physiological response from tailings (in this report, one health effect is defined as one case of cancer from exposure to radioactivity).

A process for removing uranium from ore, tailings, or other material wherein the material is placed on an impermeable pad and wetted with appropriate reagents. The uranium solution is collected for further processing.

Department of Health, Education, and Welfare. 
insult

Interim Drinking

Water Standards (EPA)

iso-exposure line

isotope

JCAE

knot

$\mu \mathrm{R} / \mathrm{hr}$

$\mathrm{mR} / \mathrm{hr}$

$\mathrm{MeV}$

MPC

NAS

NIOSH

noble gas

NRC
Negative impact on the environment or the health of individuals.

Title No. 40 of the Code of Federal Regulations, Chapter 1, Part 141, dated Dec 24, 1975; scheduled to become effective Jun 24 , 1977.

A line drawn on a map to connect all points having the same exposure rate.

One of two or more atoms with the same atomic numbers (the same chemical element) but with different atomic weights. Isotopes usually have very nearly the same chemical properties, but somewhat different physical properties.

Joint Committee on Atomic Energy.

A unit of velocity, approximately equal to $1.15 \mathrm{mi} / \mathrm{hr}$.

Microroentgen per hour.

Miliroentgen per hour.

Million electron volts.

Maximum permissible concentration (the highest concentration in air or water of a particular radionuclide permissible for occupational or general exposure without taking steps to reduce exposure).

National Academy of Sciences.

National Institute for Occupational Safety and Health.

One of the gases, such as helium, neon, radon, etc. with completely filled electron shells which is therefore chemically inert.

Nuclear Regulatory Commission. 
nuclide

ORNL

ORP-LVF (EPA)

$\mathrm{pCi} / 1$

PHS (USPHS)

$Q F$

R

rad

radioactivity

radioactive decay chain
A general term applicable to all atomic forms of the elements; nuclides comprise all the isotopic forms of all the elements. Nuclides are distinguished by their atomic number, atomic mass, and energy state.

Oak Ridge National Laboratory.

Office of Radiation Programs, Las Vegas Facility (Environmental Protection Agency).

Picocurie per liter.

Public Health Service.

Quality factor (an assigned factor which denotes the modification of the effectiveness of a given absorbed dose by the linear energy transfer).

Roentgen (a unit of exposure to ionizing radiation. It is that amount of gamma or X-rays required to produce ions carrying 1 electrostatic unit of electrical charge, either positive or negative, in 1 cubic centimeter of dry air under standard conditions, numerically equal to $2.58 \times 10^{-4}$ coulombs $/ \mathrm{kg}$ ).

The basic unit of absorbed dose of ionizing radiation. A dose of 1 rad means the absorption of 100 ergs of radiation energy per gram of absorbing material.

The spontaneous decay or disintegration of an unstable atomic nucleus, usually accompanied by the emission of ionizing radiation.

A succession of nuclides each of which transforms by radioactive disintegration into the next until a stable nuclide results. The first member is called the paront, the intermediate members are called daughters, and the final stable member is called the end product. 
radium

radon

radon background

radon concentration

radon daughter

RDC

radon flux

raffinate

recharge
A radioactive element, chemically similar to barium, formed as a daughter product of uranium (238u). The most common isotope of radium, $226 \mathrm{Ra}$, has a half-life of 1,620

yr. Radium is present in all uranium-bearing ores. Trace quantities of both uranium and radium are found in all areas, contributing to the gamma background.

A radioactive, chemically inert gas, having a half-life of 3.8 days (222 Rn): formed as a daughter product of radium $\left(226_{\mathrm{Ra}}\right)$.

Low levels of radon gas found in an area, due to the presence of radium in the soil.

The amount of radon per unit volume. In this assessment, the average value for a 24-hr period of atmospheric radon concentrations, determined by collecting data for each 30 min period of a $24-h r$ day and averaging these values.

One of several short-lived radioactive daughter products of radon (several of the daughters emit alpha particles).

Radon daughter concentration (the concentration in air of short-lived radon daughters, expressed usually in $\mathrm{pCi} / 1$; also measured in terms of working level (WL).

The quantity of radon emitted from a surface in a unit time per unit area (typical units are in pci/ $\left.\mathrm{cm}^{2}-\mathrm{sec}\right)$.

The liquid part remaining after a product has been extracted in a solvent extraction process.

The processes by which water is absorbed and added to the zone of saturation of an aquifer, either directly into the formation or indirectly by way of another formation. 
rem

residual value

riprap

sands

scintillometer

slimes

tailings

WL
(Acronym of roentgen equivalent man) The unit of dose of any ionizing radiation which produces the same biological effect as a unit of absorbed dose of ordinary $X-$ rays, numerically equal to the absorbed dose in rads multiplied by the appropriate quality factor for the type of radiation. The rem is the basic recorded unit of accumulated dose to personnel.

The value of minerals in tailings material.

An irregular wall of broken rock, placed as a retaining wall, as a protection for dikes, etc.

Relatively coarse-grained materials produced along with the slimes as waste products of ore processing in uranium mills (see tailings). These sands normally contain less radioactive material than the slimes.

A gamma-ray detection instrument normally utilizing a NaI crystal.

Extremely fine-grained materials, mixed with small amounts of water, produced along with the sands as waste products of ore processing in uranium mills (see tailings). Most of the radioactive material remaining in tailings is found in the slimes.

The remaining portion of a metalbearing ore after the metal, such as uranium, has been extracted. Tailings also may contain other minerals or metals not extracted in the process (e.g. radium).

Working level. A unit of radon daughter exposure, equal to any combination of short-lived radon daughters in 1 liter of air that will result in the ultimate emission of $1.3 \times 10^{5} \mathrm{MeV}$ of potential alpha energy. This level is equivalent to the energy produced in the 
decay of the daughter products RaA, RaB, RaC, and $\operatorname{RaC}^{\prime}$ that are present under equilibrium conditions in a liter of air containing $100 \mathrm{pCi}$ of $\mathrm{Rn}-222$. It does not include decay of RaD ( 22 yr halfiife) and subsequent daughter products.

WLM

Working level month. One WLM is equal to the exposure received from 170 WL-hours. 
CHAPTER 1

A SUMMARY OF THE PHASE II - TITLE I ENGINEERING ASSESSMENT OF RADIOACTIVE SANDS AND RESIDUES 
CHAPTER 1

\author{
A SUMMARY OF THE PHASE II - TITLE I \\ ENGINEERING ASSESSMENT OF \\ RADIOACTIVE SANDS AND RESIDUES
}

\title{
1.1 INTRODUCTION
}

The U.S. Energy Research and Development Administration (ERDA) has contracted with Ford, Bacon \& Davis Utah Inc. (FB\&DU) of Salt Lake City, Utah, to provide architect-engineering services in the assessment of the problems resulting from the existence of large quantities of radioactive uranium mill tailings at the sites of inactive mills in eight western states.

A preliminary survey (Phase I) was carried out by ERDA in cooperation with the EPA and the affected states and completed in October 1974. In the Summary Report(1), ERDA identified 17 sites in Arizona, Colorado, Idaho, New Mexico, Utah, and Wyoming for which practical remedial measures are to be evaluated. Subsequently, ERDA added five additional sites (Riverton and Converse County, Wyoming; Lakeview, Oregon; Falls City and Ray Point, Texas) to the Iist for a total of 22 sites. Most of these mills produced by far the greatest part of their output of uranium under contracts with the U.S. Atomic Energy Commission ( $A E C$ ) during the period 1947 through 1970. After operations ceased, some companies made no attempt to stabilize the tailings, while others did so with varying degrees of success. Recently, concern has increased about the possible adverse effects to the general public from long-term exposure to low-level sources of radiation from the tailings piles and sites.

To date, the studies of radiation levels on and in the vicinity of these sites have been limited in scope. The data available were insufficient to permit assessment of risk to people with any degree of confidence in the conclusions reached. In addition, information on practicable measures to reduce radiation exposures and estimates of their projected costs are limited. The purpose of this study is to develop the necessary information to provide a basis for decision-making for appropriate remedial actions for each of these sites.

In assessing the significance of the conditions existing at the Lowman site, evaluations of the following factors were included:
(a) Exhalation of radon gas from the residues
(b) On-site and off-site direct radiation
(c) Land contamination from windblown residues

(1) See end of chapter for references. 
(d) Hydrology and contamination by water pathways

(e) Potential health impact

(f) Potential for extraction of additional uranium from the sand residues

Investigation of these and other factors led to the detailed evaluation of two alternatives:

(a) Minimum remedial action, which amounts to construction of a dike and fencing, maintenance, and offsite remedial action

(b) Consolidation of the sand residue piles, stabilization with 2-ft of cover, fencing, and off-site remedial action

The estimated costs of carrying out the remedial work to implement each option depend on such parameters as the degree of decontamination to be achieved and the degree of stabilization necessary.

\subsubsection{Background}

On March 12, 1974, the Subcommittee on Raw Materials of the Joint Committee on Atomic Energy (JCAF), Congress of the United States, held hearings on S. 2566 and H.R. 11378, identical bills submitted by Senator Frank E. Moss and Representative Wayne Owens of Utah. The bills provided for a cooperative arrangement between the AEC and the state of Utah in the area of the Vitro tailings site in sale Lake City.* The bills also provided for the assessment of and appropriate remedial action to limit the exposure of individuals to radiation from uranium mill tailings.

Dr. William D. Rowe, testifying in behalf of the Environmental Protection Agency (EPA), pointed out that there are other sites with similar problems. He recommended the problem be approached as a generic one, structured to address the most critical problem first.

Dr. James L. Liverman, testifying for the AEC, proposed that a comprehensive study should be made of all such piles, rather than treating the potential problem on a piecemeal basis. He proposed

*The proceedings of these hearings and the Summary Report on the Phase I study were published by the JCAE as Appendix 3 to ERDA Authorizing Legislation for Fiscal Year 1976. Hearings before the Subcommittee on Legislation, JCAE, on Fusion Power, Biomedical and Environmental Research; Operational Safety; Waste Management and Transportation, Feb 18 and 27, 1975, Part 2. 
that the study be a cooperative two-phase undertaking by the states concerned and the appropriate federal agencies, such as the AEC and EPA. Phase I would involve site visits to determine such aspects as their condition, ownership, proximity to populated areas, prospects for increased population near the site, and need for corrective action. A preliminary report then would be prepared which would serve as a basis for determining if a detailed engineering assessment (Phase II) were necessary for each millsite. The Phase II study, if necessary, would include evaluation of the problems, examination of alternative solutions, preparation of cost estimates, and of detailed plans and specifications for alternative remedial action measures. This part of the study would include physical measurements to determine exposure or potential exposure to the public.

The Phase I assessment began in May 1974, with teams consisting of representatives of the AEC, the EPA, and the states involved visiting 21 of the inactive sites. The Phase I report was presented to the JCAE in October 1974. Table 1-1 summarized the conditions at the time of the Phase I visits. (I) Based on the findings presented in the report, the decision was made to proceed with Phase II.

On May 5, 1975, ERDA, the successor to AEC, announced that Ford, Bacon \& Davis Utah Inc. of Salt Lake City had been selected to provide the architect-engineering (A-E) services for Phase II. ERDA's Grand Junction, Colorado, office (GJO) was authorized to negotiate and administer the terms of a contract with FB\&DU. The contract was effective on June 23, 1975. The Salt Lake City Vitro site was assigned as the initial task, and work began immediately. Field work at the Lowman site was performed from september 20 through september 23, 1976.

\subsubsection{Scope of Phase II Engineering Assessment}

Phase II A-E Services are divided into two stages: Title I and Title II.

Title I services include the engineering assessment of existing conditions and the identification, evaluation and costing of alternative remedial actions for each site. Following the selection and funding of a specific remedial action plan, Title II services will be performed. These services will include the preparation of detailed plans and specifications for implementation of the selected remedial action.

This report is the assessment made for Title I requirements and was prepared by FB\&DU. The Oak Ridge National Laboratory (ORNL) at oak Ridge, Tennessee, under separate agreement with ERDA, provided measurements of the radioactivity concentrations in the soil and water samples and gamma surveys. 
The specific scope requirements of the Title I assessment as given in the contract may include but are not limited to the following:

(a) Preparation of an engineering assessment report for each site, and preparation of a comprehensive report suitable for submission to the Congress on reasonable remedial action alternatives and their estimated costs.

(b) Determination of property ownership in order to obtain release of federal government and A-E Iiability for performance of engineering assessment work at both inactive millsites and privately owned structures.

(c) Preparation of topographic maps of millsites and other sites to which tailings and other radioactive materials might be moved.

(d) Performance of core drillings and radiometric measurements ample to determine volumes of tailings and other radium-contaminated materials.

(e) Performance of radiometric surveys, as required, to determine areas and structures requiring cleanup or decontamination.

(f) Determination of the adequacy and the environmental suitability of sites to which mill tailings containing radium can be moved for long-term ( $>50$ yr) storage; and once such sites axe identified, perform evaluation and estimate the costs involved.

(g) Performance of engineering assessments of structures where uranium mill tailings have been used in off-site construction to arrive at recommendations and estimated costs of performing remedial action.

(h) Evaluation of various methods, techniques and materials for stabilizing uranium mill tailings to prevent wind and water erosion, to inhibit or eliminate radon exhalation, and to minimize maintenance and control costs.

(i) Evaluation of availability of suitable fill and stabilization cover materials that could be used.

(j) Evaluation of radiation exposures of individuals and nearby populations resulting from the inactive uranium milisite, with specific attention to:

(1) Gamma radiation 
(2) Radon

(3) Radon daughter concentrations

(4) Radium and other naturally occurring radioisotopes in the tailings

(k) Investigation of site hydrology and meteorology.

(1) Evaluation of recovering residual values, such as uranium and vanadium in the tailings and other residues on the sites.

(m) Performance of demographic and land use studies. Investigation of community and area planning, and industrial and growth projections.

(n) Evaluation of the alternative corrective actions for each site in order to arrive at recommendations, estimated costs, and socioeconomic impact based on population and land use projections.

(o) Preparation of preliminary plans, specifications, and cost estimates for alternative corrective actions for each site.

Not all of these items received attention at this site.

\subsection{SITE DESCRIPTION}

\subsubsection{Location and Topography}

The Lowman millsite is located in Boise County approximately $75 \mathrm{mi}$ northeast of Boise, Idaho in the Boise National Forest. The site is in a pine-covered mountain valley on the western slope of the Sawtooth Mountain range at an elevation of 4,000 ft above sea level. It rests on a west-facing mountain terrace. Drainage from the site is into Clear Creek just above the junction of clear Creek and the South Fork Payette River. The site and its relationship to the surrounding area are shown in the aerial photo in Figure 2-1, Chapter 2.*

\subsubsection{Ownership and History of Milling Operations and Processing}

The original owner, and only operator, was the Porter Brothers Corporation of Boise, Idaho. The site now is owned by Velsicol Chemical Corporation, the successor to the former owner, Michigan Chemical Corporation. The plant became operational in 1955 and operated until 1960. During that time approximately

\footnotetext{
*A11 figures and tables referenced in this summary are from the parent report and are included in the Addendum.
} 
200,000 tons of dredge product obtained from Bear Valley, $20 \mathrm{mi}$ north of Lowman, were processed. The process used was mechanical rather than a chemical process. Columbite-euxenite and monazite concentrates and other by-products such as magnetite, ilmenite, zircon, and garnet were extracted from the ore.

1.2.3 Present Condition of the site

Figure 2-3, Chapter 2, is a descriptive map of the site today. Some concrete foundations, a few small sheds, and some debris are all that remain of the mill structures. The just over 90,000 tons of sand residues remaining on the site are in several piles. All of these sands are radioactive to varying degrees. The radioactive sands and residues are scattered throughout the 37-acre site in 10 locations covering about 5 acres. None of these materials have been stabilized. Some of the more radioactive sands have been eroded by water down a steep slope on the west side of the site and into an old settling pond adjacent to clear Creek.

The site is about 80 \% covered with native grasses and trees, but there is no vegetation on the piles of sand. There is no fencing around the site, although some remnants of a barbed-wire fence are evident. Since the field survey work, a locked and posted gate has been installed to control vehicle access to the site.

1.2.4 Residues and Soil Characteristics

The residues are angular, dense, coarse-grained sand of several colors. Black sands are dense material, primarily magnetite; the red sands are garnet. Grey and white sands are also residues of the mechanical separation process and were deposited along the upper edge of the slope above clear creek. Table 2-1, Chapter 2 is a listing of the amounts of these materials on the site.

The soil beneath the sand residues is mountain loam, nearly black in color, with gravely aggregates resulting from glacial deposits in some locations.

1.2.5 Geology, Hydrology, and Meteorology

The Lowman millsite is located on a glacial terrace, which has been incised by clear creek to the west of the site and is bordered by a ridge to the east. A lower river-laid terrace, on which a settling pond area was constructed, is adjacent to the higher millsite terrace. The glacial terrace material is composed of deep sandy and loamy soils, gravels, sands, boulders, and cobbles. The lower alluvial terrace is river-run material primarily of granitic origin. Igneous granite bedrock (granodiorite) of the Idaho batholith underlies the site. This granite is fractured and weathered. Bedrock is exposed in the stream bed and forms the escarpment to the east of the site. Figure 2-4, Chapter 2 is a 
simplified stratigraphic section of the area.

The flowing surface waters near the site consist of clear Creek, the South Fork Payette River, and the intermittent flow in ditches on the site. Clear creek is a swiftly flowing stream that intersects the South Fork Payette River approximately 0.5 $\mathrm{mi}$ south of the site. It is possible that the lower terrace which borders the creek could be eroded by flood waters of clear creek, with resulting undercutting and erosion of the residue piles. However, there is no evidence that such flooding has occurred.

Contamination of the surface waters could occur by physical transport of the sands as a result of overland runoff and by seepage through the pile into the waters. Placement of the pile parallel to the slopes, which tends to trap water behind the pile, has encouraged seepage into the surface waters. The degree of physical transport from the site has been aggravated by the steep banks of the sparsely vegetated piles, where some slopes have gullies up to $10 \mathrm{ft}$ deep. Rill erosion is occurring on the cut behind and adjacent to the mill foundations. The ridge east of the pile limits the catchment area near the site; however, a substantial trench was constructed to convey process water from the eastern slope to the mill during operations. This ditch continues to channel runoff, and this concentration of flow aggravates erosion.

Shallow unconfined aquifers characterize the hydrology of the area. Clear Creek and the South Fork Payette River are gaining streams fed by flows from unconfined ground waters. The terrace materials tend to filter sediments from the waters and act as buffers to regulate overland and subsurface flow. The interface between the unconsolidated surficial materials and bedrock acts as the surface for lateral ground water flow. Seeps and springs are common in the area, particularly at the exposure of this interface. One such spring lies at the southern margin of the pile relatively near the source of domestic water for a trailer home. Three wells in the area are federal government wells, but they have not been monitored. There is no problem associated with confined ground waters at the site because there are no confined ground waters associated with the igneous bedrock of the Idaho batholith.

Average annual precipitation at the site ranges between 20 to $25 \mathrm{in.}$ much of which comes as snow pack. High-intensity rainstorms are infrequent, but such a storm at the site could result in serious erosion of the more susceptible areas of the pile. The strongest winds blow up and down the valley in a north-south direction, but the local land relief and the forest canopy tend to act as windbreaks and protect the sands from wind erosion.

\subsection{RADIOACTIVITY AND POLLUTANT IMPACTS ON THE ENVIRONMENT}

A significant fraction of the total radioactivity originally in the ore remained in the residue sands after processing. The 
principal environmental radiological impact and associated health effects arise from the ${ }^{23} 0_{\mathrm{Th}}, 226 \mathrm{Ra},{ }^{222} \mathrm{Rn}$, and $222_{\mathrm{Rn}}$ daughters contained in the residue sands. Although these radionuclides occur in nature, their concentrations in the residue sands are several orders of magnitude greater than their average concentrations in the earth's crust.

1.3.1 Radiation Exposure Pathways, Contamination Mechanisms, and Background Levels are:

The major potential environmental routes of exposure to man

(a) Inhalation of $222_{\mathrm{Rn}}$ and its daughter products, resulting from the continuous radioactive decay of $226 \mathrm{Ra}$ in the tailings. Radon is a gas which diffuses from the pile. The principal exposure results from inhalation of the $222 \mathrm{Rn}$ and $\mathrm{Rn}$ daughters. This exposure affects the lungs. For this assessment, no criteria have been established for radon concentrations in air. However, the pathway for radon and radon daughters accounts for the major portion of the exposure to the population.

(b) External whole-body gamma exposure directly from radionuclides in the pile.

(c) Inhalation and ingestion of windblown tailings. The primary health effect relates to the alpha. emitters $230^{0} \mathrm{Th}$ and $226 \mathrm{Ra}$, each of which causes exposure to the bones and lungs.

(d) Ingestion of ground and surface water contaminated with radioactive elements (primarily $226_{\mathrm{Ra}}$ ) and other toxic materials.

(e) Contamination of food through uptake and concentration of radioactive elements by plants and animals is another pathway which can occur; however, this pathway was not considered in this study.

1.3.1.1 Radon Gas Diffusion and Transport

Short-term radon measurements were performed with the ERDAsupplied continuous radon monitors at six locations in the vicinity of the Lowman piles. The locations and values of the radon measurements are shown in Figure 3-3, Chapter 3. The one 24-hr on-site measurement averaged only $1.8 \mathrm{pCi} / 1$ of radon. Four $24-\mathrm{hr}$ measurements of atmospheric radon indicated an average background concentration of $1.2 \mathrm{pCi} / 1$ for the Lowman area.

1.3.1.2 Direct Gamma Radiation

The range of natural background values in the Lowman area was 
between 10 and $12 \mu \mathrm{R} / \mathrm{hr}$, averaging $11 \mu \mathrm{R} / \mathrm{hr}$ as measured with an energy-compensated Geiger Mueller detector. (2) Above the surface of the ore piles, gamma rates were measured as high as 2,450 $\mu \mathrm{R} / \mathrm{hr}$ and $1,220 \mu \mathrm{R} / \mathrm{hr}$ over the residue piles.

\subsubsection{Windblown Contaminants}

Background gamma radiation rates were reached within $0.2 \mathrm{mi}$ to the north and $0.1 \mathrm{mi}$ in the other directions from the site. The results of the EPA gamma radiation survey around the site are shown in Figure 3-9, Chapter 3. The background Iine closely follows the area where the piles are located.

A surface soil sample taken $0.1 \mathrm{mi}$ north of the site contained 4 times background levels of $226_{\mathrm{Ra}}(1.1 \mathrm{pCi} / \mathrm{g})$. On-site soil samples had radium concentrations from background to 15 times average radium background concentration. However, one sample near Clear Creek and near the base of the grey sand pile contained 200 $\mathrm{pci} / \mathrm{g}$ of radium. This sample probably contained sand eroded from the pile by surface run-off.

\subsubsection{Ground and Surface water Contamination}

Two surface water samples from clear creek upstream and downstream from the Lowman site were analyzed for $226 \mathrm{Ra}$. The upstream sample contained $0.16 \mathrm{pCi} / 1$ of radium; only a trace of radium was found in the downstream sample. The radium content of water from a spring south of the site was $0.12 \mathrm{pCi} / 1$. These results indicate no contamination of ground and surface water from radium leached from the piles.

\subsubsection{Soil Contamination}

The transport of radium into the subsoil beneath the piles extends to 2 to 3 ft below the pile-subsoil interface before reaching twice the average background level of radium concentration in local soil samples $(1.1 \mathrm{pCi} / \mathrm{g})$. A few isolated locations were found where deeper contamination exists.

\subsubsection{Remedial Action Criteria}

Radiological criteria established for this engineering assessment are divided into two general categories:

(a) Criteria applicable to structures with tailings underneath them or within $10 \mathrm{ft}$

(b) Criteria pertaining to the mill tailings site and open 1and

The criteria utilized for habitable structures are the guidelines published by the Surgeon General of the United States for use in the Grand Junction, Colorado, remedial program. These guidelines recommend graded levels (based on yearly average val- 
ues) for remedial action in terms of the external gamma radiation (EGR) levels and of the indoor radon daughter concentration (RDC) levels above background found within dwellings constructed on or near uranium mill tailings. (In this usage, the word "external" refers to gamma radiation from sources outside the human body to which an individual may be exposed.)

The recommended graded levels are as follows:

$\underline{\text { EGR }} \quad \underline{R D C}^{\mathrm{a}}$

Greater than

$0.1 \mathrm{mR} / \mathrm{hr}^{\mathrm{b}}$

From 0.05 to

$0.1 \mathrm{mR} / \mathrm{hr}$

Less than

$0.05 \mathrm{mR} / \mathrm{hr}$
Greater than

$0.05 \mathrm{WL}^{\mathrm{C}}$

From 0.01 to

$0.05 \mathrm{WL}$

Less than

$0.01 \mathrm{WL}$
Recommendations

Remedial action indicated

Remedial action may be suggested

No remedial action indicated

abased upon yearly average values from 6 air samples of at least 100-hr duration taken at a minimum of 4-wk intervals throughout the year.

$b_{\mathrm{mR} / \mathrm{hr}}=$ milliroentgen per hour, a measure of gamma radiation; $1 \mathrm{mR} / \mathrm{hr}=1,000 \mu \mathrm{R} / \mathrm{hr}$.

CWL = working level, a measure of alpha radiation from short-lived radon daughter elements.

The criteria for land decontamination have the objective of reducing residual gamma radiation to levels which are as low as practicable. However, topographic and economic considerations frequently preclude complete decontamination. A provisional maximum of $40 \mu \mathrm{R} / \mathrm{hr}$ above background is used in such circumstances. Average background in the Lowman area was determined in this study to be $11 \mu \mathrm{R} / \mathrm{hr}$. As a guideline for the land beyond the site, if residual gamma levels are less than $10 \mu \mathrm{R} / \mathrm{hr}$ above background, the land may be released for unrestricted use. Where cleanup is necessary the radium content of the soil should be reduced to no more than twice the radium background in the area. If the radioactive tailings material is stabilized in place, the same criteria apply but control of gamma radiation would be by an earth covering. However, the area should be designated a controlled area, be fenced to limit access, and be restricted as to human occupancy. The numerical guidelines provide a basis for the engineering assessment, but are subject to review based on the overall findings of Phase II.

The ${ }^{226} \mathrm{Ra}$ content of ground and surface water should meet applicable state and federal standards. 


\subsubsection{Potential Health Impact}

Radon gas exhalation from the sands and residue piles and the subsequent inhalation of radon daughters account for most of the total dose to the population from the Lowman site under present conditions. The gamma radiation exposure from the piles is essentially zero, since there are very few persons who live or work within $0.2 \mathrm{mi}$ of the piles where gamma radiations are above background.

Gamma radiation can be reduced effectively by shielding with any dense material. However, experience has shown that it is very difficult to control the movement of radon gas through porous solid cover materials. Once released from the radium-bearing minerals in the tailings, the gaseous radon diffuses by the path of least resistance to the surface. The radon has a half-life of about 4 days, and its daughter products are solids. Therefore, part of the radon decays en route to the surface and leaves daughter products within the tailings piles. If the diffusion path can be made long enough, then, theoretically, substantially all the radon and its daughter products can be made to decay before escaping to the atmosphere. Calculations using the techniques of Kraner, schroeder, and Evans(3) indicate that 13 ft of earth cover theoretically would be required to reduce the radon diffusion from the Lowman tailings by $95 \%$.

The health significance to man of long-term exposure to radiation is a subject that has been studied extensively for many years. The end result of long-term exposure to low-level radiation is increased susceptibility to diseases such as lung cancer or leukemia, which also are attributable to many other causes. Thus, the determination of specific cause in any given case becomes very difficult. Therefore, the usual approach to evaluation of the health impact of low-level radiation exposures is to make projections from observed effects of high exposures on the premise that the effects are linear. A considerable amount of information has been accumulated on the high incidence of lung cancer in uranium miners exposed to radon and its daughters in mine air. This provides a basis for calculating the probable health effects of lowlevel exposure to large populations. (The term "health effect" refers to an incidence of disease; for radon daughter exposure, 1 health effect $=1$ case of lung cancer.) This is the basis of the health effects calculations in this report. It should be recognized, however, that there is a large degree of uncertainty in such projections. Among the complicating factors is the combined effect of radon daughters with other carcinogens. As an example, the incidence of lung cancer among uranium miners who smoke is far higher than can be explained on the basis of either smoking or the radiation alone.

The risk estimators used in this report are given in the report of the National Academy of Sciences Advisory Committee on the Biological Effects of Ionizing Radiation (BEIR report). (4) This report presents risk estimators for lung cancer derived from 
epidemiological studies of both uranium miners and fluorspar miners. The average of the absolute risk estimator for these two groups is: 6 cancers per year per $10^{6}$ person-WLM exposure. The term WLM means working level month, or an exposure to a concentration of one working level of radon daughter products in air for $170 \mathrm{hr}$, which is a work-month. A working level (WL) is a unit of measure of radon daughter products which recognizes that the several daughter elements are frequently not in equilibrium with each other nor with the parent radon. Because of the many factors which contribute to natural biological variability, and of the many differences between exposure conditions in mines and residences, this estimator (6 cancer cases per year per $10^{6}$ person-WLM) is considered to have an uncertainty factor of about 3 . The relative risk estimator can be several factors larger than the absolute risk estimator. (5)

For the purpose of the Lowman sand residue assessment, it was assumed that about $50 \%$ equilibrium exists inside structures between radon and its daughter elements resulting in the following conversion factors:

$$
1 \mathrm{pCi} / 1 \text { of } 222 \mathrm{Rn}=0.005 \mathrm{WL}
$$

For continuous exposure:

$$
0.005 \mathrm{WL}=0.25 \mathrm{WLM} / \mathrm{Yr}
$$

On the basis of predictions of radon concentrations in excess of background values, it is estimated that the pile radon-induced lung cancer risk to individuals $0.5 \mathrm{mi}$ from the site is $2.2 \times 10^{-6}$ per person per year. The health effect rate for background radon is approximately $5.2 \times 10^{-5}$ per person per year, or about 24 times that attributable to pile radon. The average lung cancer risk due to all causes for Idaho residents is $1.0 \times 10^{-4}$ per person per year. (6)

As a result of the low population density and the low radiation levels of the sand residues at the Lowman site, the potential health impact of the piles is minimal.

\subsubsection{Nonradioactive Pollutants}

Four water samples were taken from the vicinity of the Lowman site and analyzed for heavy metal content. Two samples were from Clear creek upstream and downstream from the site, and two samples were from a well and a spring downgradient from the site. None of the samples indicated leaching of nonradioactive heavy metals from the site.

\subsection{SOCIOECONOMIC AND LAND USE IMPACTS}

The area near the site is used as forest land or for recreation. Much of the land is administered by the U.S. Forest Service. There are no population concentrations near the site, although the community of Lowman has a general store, a service 
station, a lodge, and a motel. Some of the private tracts near the site have been subdivided into 1-acre lots for summer homes. one such tract is located across the river from the site. Projected land uses are similar to present land uses, with increased development of lots for year-round as well as for vacation purposes.

Single 1-acre lots sell for approximately $\$ 2,500$ near the site area. The presence of the residue sands has not affected land uses or values of nearby land, although the use of the site has been restricted by the sands and the aesthetic quality of the site has been diminished by the sparsely vegetated slopes and abandoned property on the site.

\subsection{RECOVERY OF RESIDUAL VALUES}

Estimates of the uranium content of the 15,000 tons of gray sand residues and ore at the site by the AEC indicate an average $\mathrm{U}_{3} \mathrm{O}_{8}$ concentration of $0.19 \%$.

The Lowman ore was processed using physical separation methods; consequently, the conventional chemical techniques would not be economically feasible. In addition, the limited amount of material available precludes economic recovery.

\subsection{MILL TAILINGS STABILIZATION}

Present practices and technology of mill tailings stabilization are being examined. This investigation indicates that much research and development remains to be performed before complete and permanent stabilization of radioactive mill tailings can be realized.

Reasonably effective means of wind and water erosion control are available, although they will involve continued maintenance costs. Iining of containment areas or chemical solidification of the tailings are possible methods for control of leaching.

Up to this time, no attempt has been made to contain radon in a tailings pile. Although a thick earth cover is theoretically effective, it has not actually been tried. The observed variability of radon exhalation rates indicates that with better understanding of the mechanism involved, control may be possible.

Option II includes consolidation and stabilization of the residue piles with 2 ft of earth cover. This cover would greatly reduce the water erosion presently occurring. Gamma radiation would be reduced to background levels but radon exhalation would be reduced only $30 \%$ by the 2 -ft thickness of cover material.

\subsection{OFF-SITE REMEDIAL ACTION}

A mobile scanning unit, operated by the AEC under interagency agreement for the EPA, was used to perform a gamma radiation sur- 
vey of the Lowman, Idaho area prior to 1973. A subsequent field survey identified seven off-site areas where use of the radioactive sands was suspected or confirmed. The cost of remedial action for these locations has been estimated to be $\$ 50,000$. No significant contamination from windblown sands has been detected; thus, no separate cost for cleanup of windblown sands has been included. Therefore, the total remedial action estimated cost for off-site structures is $\$ 50,000$, exclusive of engineering costs and contingency.

An extended series of measurements, such as required in the full application of the Grand Junction remedial action criteria, might modify the actual number of locations included in the remedial action. The location at which tailings are on vacant lands or are greater than $10 \mathrm{ft}$ from structures could constitute a problem in the future. Costs for this category are not included in this assessment because they are not covered under the Grand Junction remedial action criteria.

\subsection{LONG-TERM STORAGE SITE SELECTION}

No alternative disposal site has been considered for the Lowman radioactive residue sands. With implementation of option II, the sands would be isolated hydrologically in a pit with a compacted clay liner and stabilized at the present site to meet the criteria for long-term storage.

\subsection{REMEDIAL ACTIONS AND COST BENEFIT ANALYSES}

\subsubsection{Remedial Action Options}

The two remedial actions are summarized in Table 1-2.

Option I consists of construction of an earthen dike between Clear Creek and the grey sand residue, installation of security fencing surrounding the site, and annual monitoring and maintenance. Also included is corrective action at two off-site locations where the radioactive sands were used in construction activities. The estimated cost of option I is $\$ 330,000$.

Under option II, all of the radioactive materials and debris would be gathered onto one pile on the site, then stabilized with $2 \mathrm{ft}$ of earth cover and isolated hydrologically from the environment. The resulting 4 -acre pile would be fenced. Monitoring, maintenance, and off-site remedial action would be as in option $I$. The estimated cost of option II is $\$ 520,000$.

\subsubsection{Cost-Benefit Analyses}

The principal reasons for adoption of the two remedial options are (a) to reduce further deterioration of site conditions through control of erosion, and (b) to limit access so that the sands cannot be removed from the site. Population and off-pile radiation levels are so small that the health benefits associated with the remedial actions are negligible. 
TABLE 1-1

SUMMARY OF CONDITIONS NOTED AT TIME OF PHASE I SITE VISITS ${ }^{a}$

\begin{tabular}{|c|c|c|c|c|c|c|c|c|c|c|}
\hline & $\begin{array}{l}\text { Cond. } \\
\text { of } \\
\text { Tailings }\end{array}$ & $\begin{array}{l}\text { Cond. of } \\
\text { Structures } \\
\text { on site }\end{array}$ & $\begin{array}{l}\text { Mil1 } \\
\text { Housing }\end{array}$ & $\begin{array}{l}\text { Adequate } \\
\text { Fencing, } \\
\text { Posting, } \\
\text { Security }\end{array}$ & $\begin{array}{l}\text { Property } \\
\text { Close by } \\
\text { River or } \\
\text { Stream }\end{array}$ & $\begin{array}{l}\text { Houses- } \\
\text { Industry } \\
y / \text { in } 1 / 2 \\
\text { Mile }\end{array}$ & $\begin{array}{l}\text { Evidence } \\
\text { of Wind } \\
\text { Watex } \\
\text { Erosion }\end{array}$ & $\begin{array}{l}\text { Possible } \\
\text { Water } \\
\text { Contami- } \\
\text { nation }\end{array}$ & $\begin{array}{l}\text { Tailings } \\
\text { Removed } \\
\text { for Pri- } \\
\text { vate Use }\end{array}$ & $\begin{array}{l}\text { Other } \\
\text { Hazards } \\
\text { On-site }\end{array}$ \\
\hline \multicolumn{11}{|l|}{ ARIZONA } \\
\hline Monument & $\mathrm{U}$ & $\mathbf{R}$ & $\mathbf{N}$ & No & No & Yes & No & No & No & No \\
\hline Tuba city & $\mathrm{U}$ & $\mathrm{PR}-\mathrm{UO}$ & $E-O$ & No & No & Yes & Yes & No & No & Yes \\
\hline \multicolumn{11}{|l|}{ COLORADO } \\
\hline Durango & $\mathrm{P}$ & PR-UO & $\mathbf{N}$ & Yes & Yes & Yes & Yes & No & Yes & Yes \\
\hline Grand Junction & $\mathbf{s}$ & $\mathrm{PR}-\mathrm{O}$ & $\mathbf{N}$ & Yes & Yes & Yes & No & No & Yes & No \\
\hline Gunn ison & $\mathbf{s}$ & $\mathrm{B}-\mathrm{O}$ & $\mathrm{N}$ & Yes & No & Yes & No & Yes & No & No \\
\hline Maybe 11 & $\mathbf{S}$ & $\mathbf{R}$ & $\mathbb{N}$ & Yes & No & No & No & No & No & No \\
\hline Naturita & $\mathbf{s}$ & PR-O & $E-P$ & Yes & Yes & No & Yes & Yes & No & No \\
\hline New Rifle & $\mathbf{P}$ & $\mathrm{M}-\mathrm{O}$ & $\mathbb{N}$ & Yes & Yes & Yes & Yes & Yes & No & No \\
\hline Old Rifle & $\mathbf{s}$ & PR-UO & $\mathrm{N}$ & Yes & Yes & Yes & No & Yes & Yes & No \\
\hline Slick Rock (NC) & ) $s$ & $\mathrm{R}$ & $\mathrm{N}$ & No & Yes & Yes & Yes & No & No & No \\
\hline $\begin{array}{l}\text { Slick Rock } \\
\text { (UCC) }\end{array}$ & $S$ & $\mathbf{R}$ & $E-P$ & Yes & Yes & Yes & No & No & No & No \\
\hline \multicolumn{11}{|l|}{ IDAHO } \\
\hline Lowman & $\mathrm{U}$ & $\mathrm{R}$ & $N$ & No & Yes & Yes & No & No & Yes & No \\
\hline \multicolumn{11}{|l|}{ NEW MEXICO } \\
\hline Ambrosia Lake & $U$ & PR -0 & $\mathrm{~N}$ & Yes & No & No & Yes & No & No & No \\
\hline Shiprock & $\mathbf{P}$ & PR-O & $E-O$ & Yes & Yes & Yes & No & No & Yes & Yes \\
\hline \multicolumn{11}{|l|}{ OREGON } \\
\hline Lakeview & $\mathrm{U}$ & $M-U O$ & $\mathrm{~N}$ & Yes & No & Yes & Yes & No & No & No \\
\hline \multicolumn{11}{|l|}{ TEXAS } \\
\hline Falls City & $\mathrm{P}$ & $M-U O$ & $\mathrm{~N}$ & Yes & No & No & No & No & No & No \\
\hline Ray Point & $\mathrm{P}$ & $\mathrm{M}-\mathrm{UO}$ & $\mathrm{N}$ & Yes & No & No & No & No & No & No \\
\hline
\end{tabular}


TABLE $1-1$ (Cont)

\begin{tabular}{|c|c|c|c|c|c|c|c|c|c|c|}
\hline & $\begin{array}{l}\text { Cond. } \\
\text { of } \\
\text { Tailings }\end{array}$ & $\begin{array}{l}\text { Cond. of } \\
\text { structures } \\
\text { on site }\end{array}$ & $\begin{array}{l}\text { Mill } \\
\text { Housing }\end{array}$ & $\begin{array}{l}\text { Adequate } \\
\text { Fencing. } \\
\text { Posting, } \\
\text { Security }\end{array}$ & $\begin{array}{l}\text { Property } \\
\text { Close by } \\
\text { River or } \\
\text { Stream }\end{array}$ & $\begin{array}{l}\text { Houses- } \\
\text { Industry } \\
\text { w/in } 1 / 2 \\
\text { Mile }\end{array}$ & $\begin{array}{l}\text { Evidence } \\
\text { of wind } \\
\text { Water } \\
\text { Erosion }\end{array}$ & $\begin{array}{l}\text { Possible } \\
\text { Water } \\
\text { Contami- } \\
\text { nation }\end{array}$ & $\begin{array}{l}\text { Tailings } \\
\text { Removed } \\
\text { for Pri- } \\
\text { vate Use }\end{array}$ & $\begin{array}{l}\text { Other } \\
\text { Hazards } \\
\text { On-site }\end{array}$ \\
\hline \multicolumn{11}{|l|}{ UTAH } \\
\hline Green River & $\mathbf{S}$ & $8-0$ & $\mathbf{N}$ & Yes & No & Yes & Yes & Yes & No & No \\
\hline Mexican Hat & $\mathrm{U}$ & $B-O$ & $E-O$ & No & No & Yes & Yes & Yes & No & No \\
\hline salt Lake City & $\mathrm{U}$ & $\mathbb{R}$ & $\mathbf{N}$ & No & Yes & Yes & Yes & Yes & Yes & Yes \\
\hline \multicolumn{11}{|l|}{ WXOMING } \\
\hline Converse County & $U$ & $\mathbf{R}$ & $\mathbf{N}$ & No & No & No & No & No & No & No \\
\hline
\end{tabular}

\footnotetext{
(1) S - stabilized but requires improvement

P - Partially stabilized

岗 U-Unstabilized.
}

(2) M - Mill intact

(3) N - None

B - Building(s) intact

E - Existing

$R$ - Mill and/or buildings removed

o- occupied

PR- Mill and/or buildings partially removed

P - Part occupied.

o - Occupied or used

UO- Unoccupied or unused. 
TABLE $1-2$

SUMMARY OF REMEDIAL ACTION OPTIONS AND EFFECTS

\begin{tabular}{|c|c|c|c|c|}
\hline $\begin{array}{l}\text { Option } \\
\text { Number }\end{array}$ & $\begin{array}{l}\text { Cost }^{1} \\
(\$ 000) \\
\end{array}$ & Description & Benefits & $\begin{array}{l}\text { Adverse } \\
\text { Effects }\end{array}$ \\
\hline$I$ & 330 & $\begin{array}{l}\text { Dike construction, fencing, } \\
\text { monitoring, maintenance, and } \\
\text { off-site remedial action }\end{array}$ & $A, B$ & $\mathrm{~V}, \mathrm{~W}, \mathrm{X}, \mathrm{Y}$ \\
\hline II & 520 & $\begin{array}{l}\text { Consolidation of sands, } 2 \text {-ft } \\
\text { stabilization, fencing, moni- } \\
\text { toring, maintenance, and off- } \\
\text { site remedial action }\end{array}$ & $\begin{array}{l}A, B, C, D, \\
E, E, G\end{array}$ & Z \\
\hline
\end{tabular}

Definition of Benefits

A. Better security

B. Sands kept from entering river

C. Sands protected from erosion by wind or water

D. Gamma radiation reduced to near-background levels

E. Radon exhalation reduced by $30 \%$

F. Minimum maintenance required

G. Large portion of site available for other purposes

Definition of Adverse Effects

V. Iittle decrease in erosion

W. No decrease in gamma radiation

$X$. No decrease in radon exhalation

Y. Entire site completely unusable for any purpose

Z. Part of site completely unusable for any purpose

Note

${ }^{1}$ Costs are in 1977-value dollars 
1. "Summary Report, Phase I Study of Inactive Mill Sites and Tailings Piles"; AEC; Grand Junction, Colorado; Oct 1974.

2. F. F. Haywood, et al; "Assessment of Radiological Impact of the. Inactive Uranium Mill Tailings Pile at Lowman, Idaho"; ORNL (in preparation).

3. H. W. Kraner, G. L. Schroeder, and R. D. Evans; "Measurements of the Effects of Atmospheric Variables on Radon-222 Flux and. Soil-Gas Concentrations" ; The Natural Radiation Environment; J. A. S. Adams and W. M. Lowder, eds; University of Chicago Press; 1964.

4. "The Effects on Populations of Exposure to Low Levels of Ionizing Radiation"; Report of Advisory Committee on Biological Effects of Ionizing Radiation; NAS, National Research Council; Nov 1972 .

5. "Health Effects of Alpha-Emitting Particles in the Respiratory Tract"; Report of the Advisory Committee on the Biological Effects of Ionizing Radiation; EPA-520/4-76-013; EPA; Office of Radiation Programs; Washington, D.C.; Oct 1976.

6. Vital Statistics of the U.S.; Vol II; Mortality; National Center for Health Statistics; HEW; 1968. 
ADDENDUM

FIGURES AND TABLES

$1-19$ 
Number

$2-1$

$2-3$

$2-4$

$3-3$

$3-9$
Title

$\underline{\text { Page }}$

Aerial Photo of Site . . . . . . 2-6

Descriptive Map . . . . . . . . . 2-8

Simplified Stratigraphic Section . . . 2-9

Radon Concentration in Vicinity

of Pile . . . . . . . . . . 3-15

EPA Gamma Surveys Surrounding

Millsite.... . . . . . . . . 3-21

\section{LIST OF TABLES}

Number

$2-1$
Title

Page

Site Residue Materials . . . . . . 2-12 


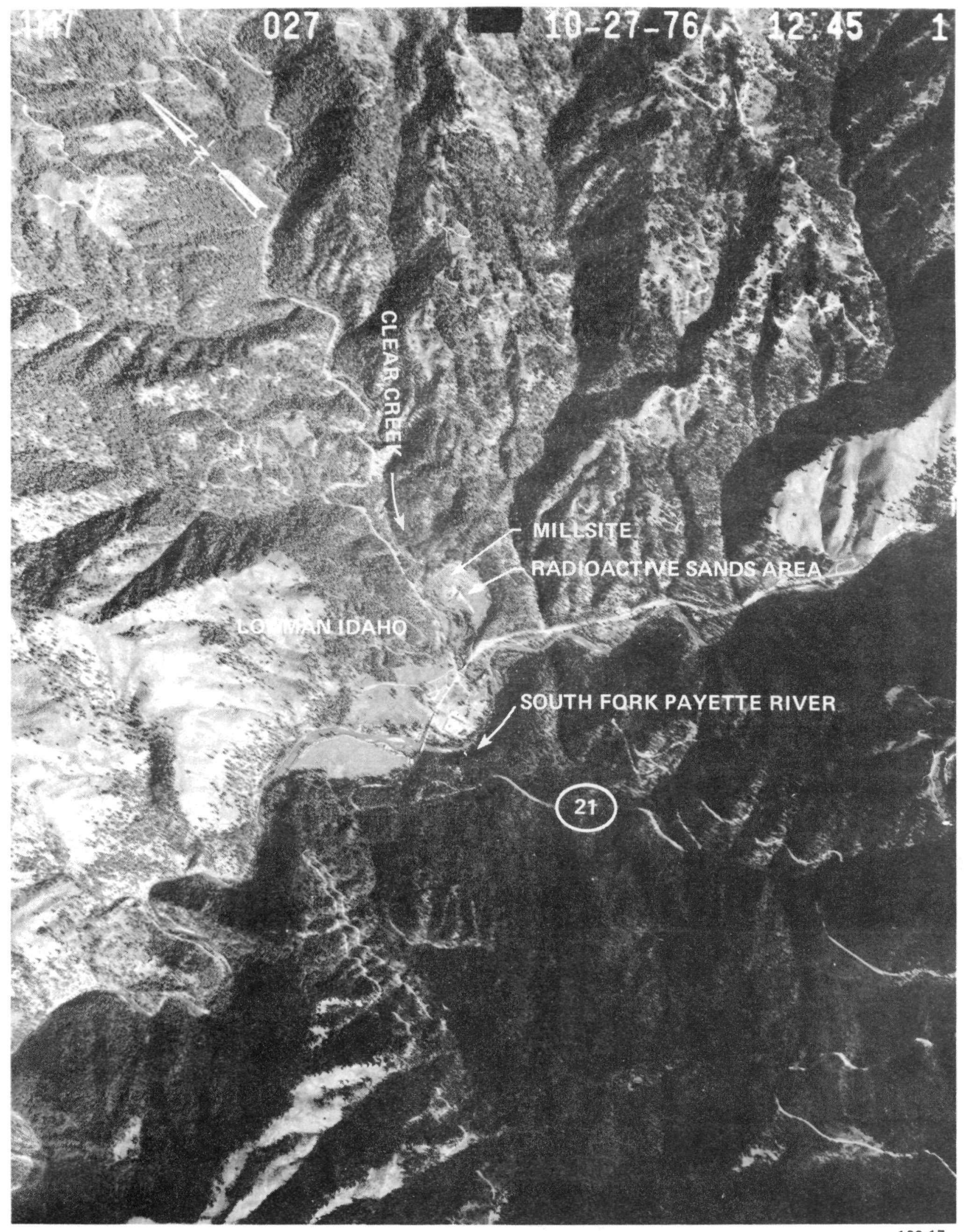

$130-17$

FIgURE 2-1. AERIAL PHOTOGRAPH OF SITE 


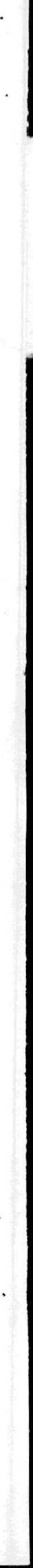




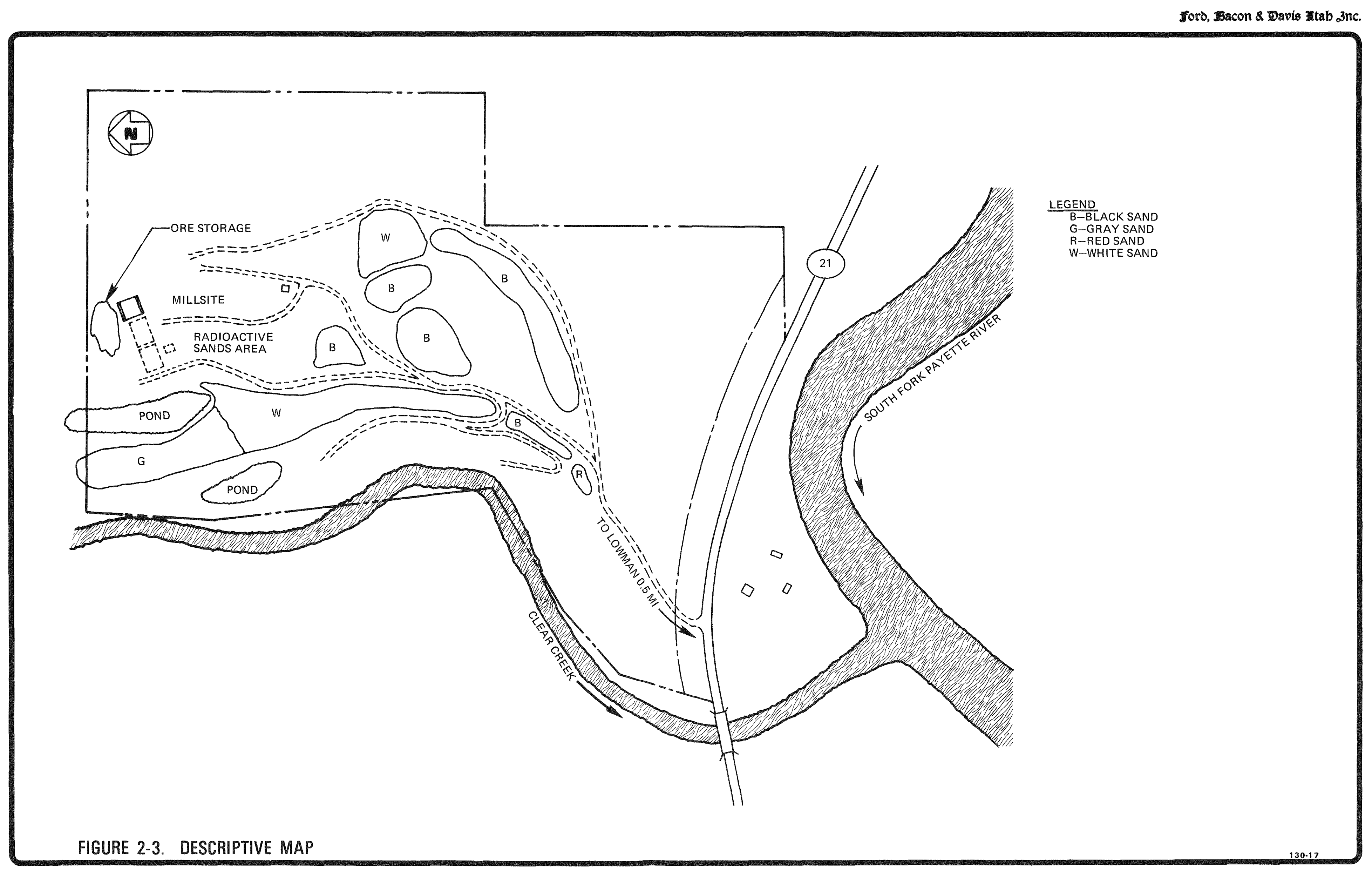




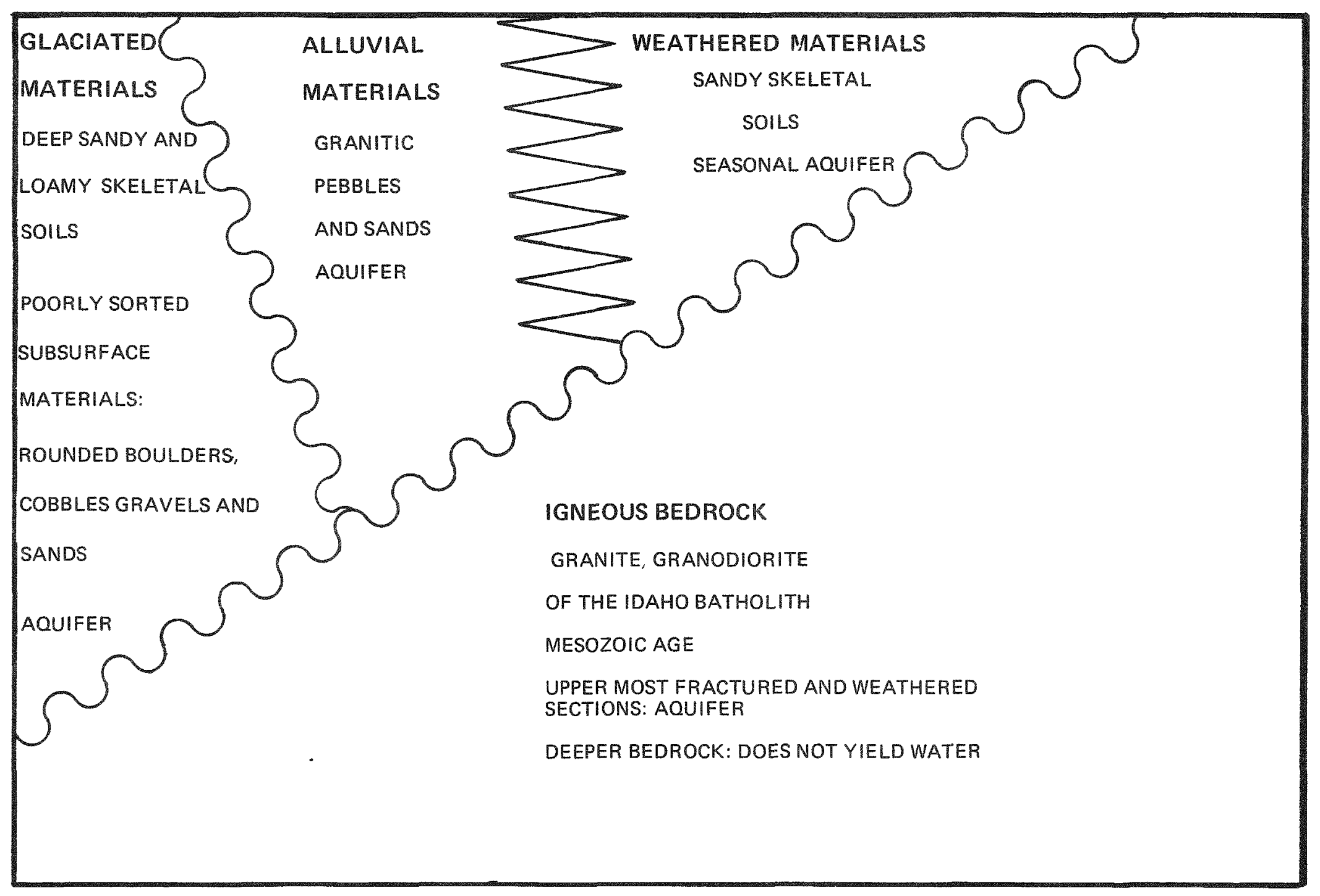

FIGURE 2-4 SIMPLIFIED STRATIGRAPHIC SECTION 



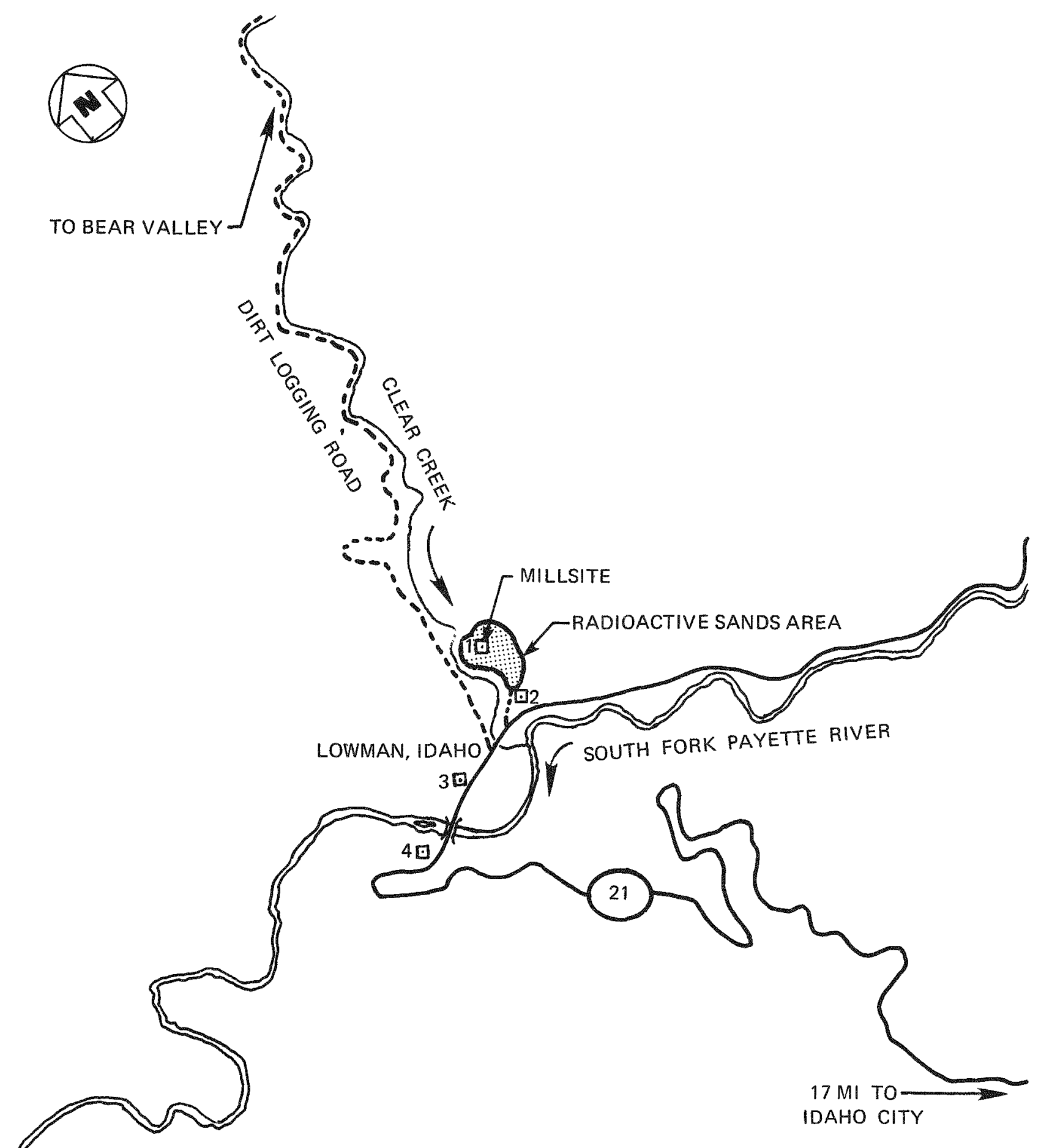

\begin{tabular}{|c|c|c|c|l|}
\hline DATE & SITE NO. & $\begin{array}{c}24 \mathrm{HR} \\
\text { OUTDOOR } \\
(\mathrm{pCi} / 1)\end{array}$ & $\begin{array}{c}24 \mathrm{HR} \\
\text { INDOOR } \\
(\mathrm{pCO} / / 1)\end{array}$ & LOCATION \\
\hline $9 / 21 / 76$ & 1 & 1.8 & - & FORMER MILLSITE AREA \\
\hline $9 / 20 / 76$ & 2 & $1.1^{*}$ & - & AT GATE TO SITE, 0.1 MIS \\
\hline $9 / 21 / 76$ & 3 & $1.1^{*}$ & - & 0.25 MI SW OF SITE \\
\hline $9 / 20 / 76$ & 4 & 1.2 & 1.1 & MOTEL, 0.5 MI SW OF SITE \\
\hline $9 / 22 / 76$ & 5 & $1.3^{*}$ & - & 2.0 MI E OF SITE \\
\hline $9 / 22 / 76$ & 6 & $1.1^{*}$ & 1.2 & $\begin{array}{l}\text { SERVICE STATION } \\
\text { 3.75 MI E OF SITE }\end{array}$ \\
\hline
\end{tabular}

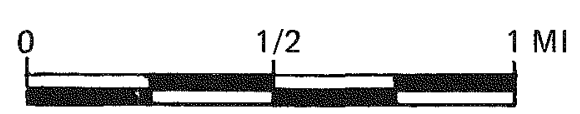





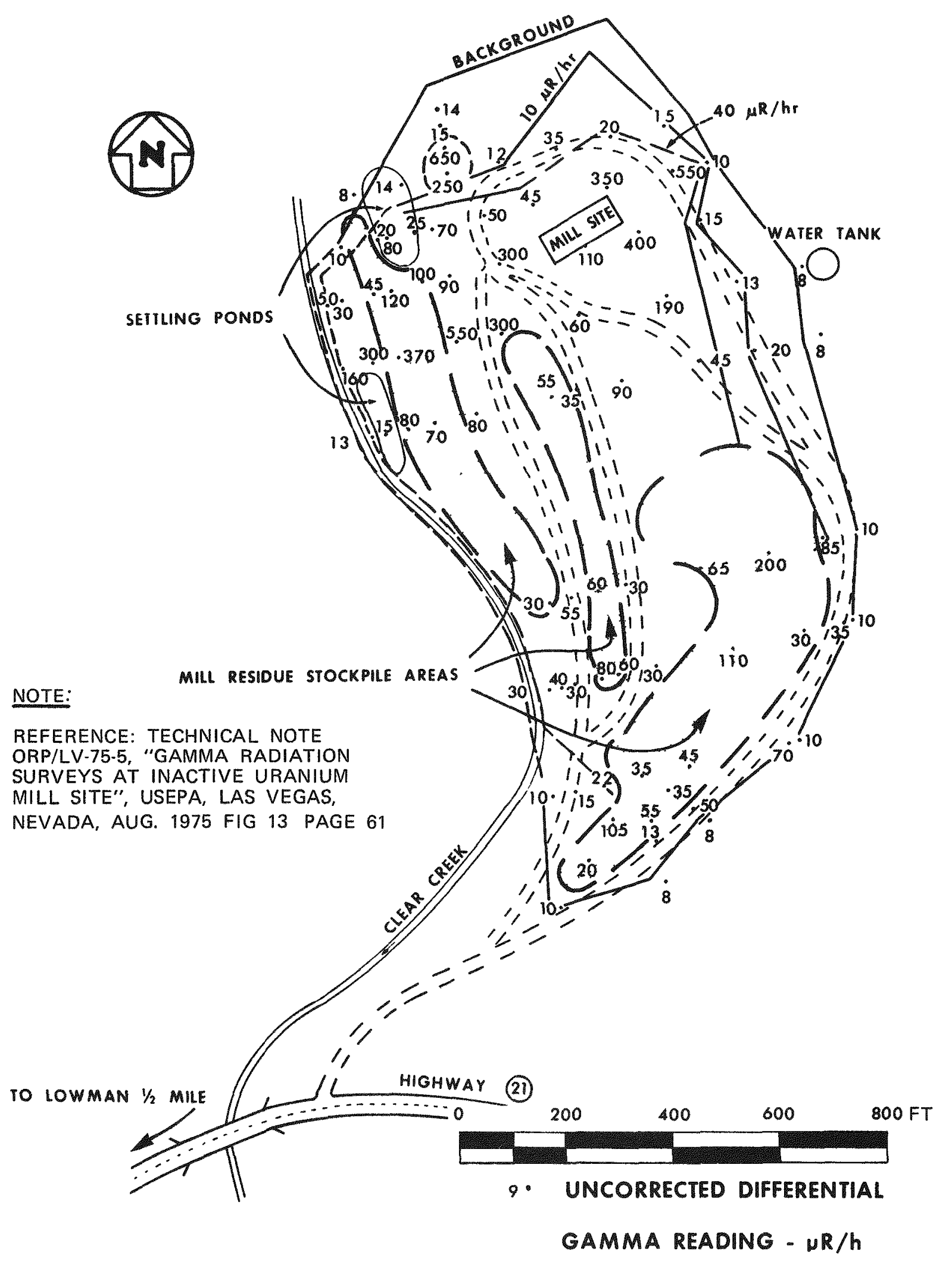

FIGURE 3-9. EPA GAMMA SURVEY SURROUNDING MILLSITE 

TABLE 2-1

SITE RESIDUE MATERIALS

Material

White Sand

Black Sand

Grey Sand Residue

Original Source Ore
Weight (Tons)

50,000

23,000

10,000

5,000

90,000 $\div \mathrm{U}_{3} \mathrm{O}_{8}$

0.01

0.02

0.18

0.22

Rounded Total 